\title{
MACIEJ JABŁOŃSKI
}

Instytut Ekologii i Bioetyki, UKSW, Warszawa

\section{Prawno-administracyjny charakter koncesji w ustawie Prawo energetyczne}

Słowa kluczowe: koncesje, administracja publiczna, energetyka, ochrona środowiska Key words: concessions, public administration, energetics, environmental protection

Zgodnie z unormowaniami ustawy - Prawo energetyczne (A), jak stanowi art. 32 ust.1 uzyskania koncesji wymaga wykonywanie działalności gospodarczej w zakresie:

1) wytwarzania paliw lub energii, $z$ wyłączeniem wytwarzania:

a. paliw stałych lub paliw gazowych,

b. energii elektrycznej w źródłach o łącznej mocy zainstalowanej elektrycznej nieprzekraczającej $50 \mathrm{MW}$ niezaliczanych do odnawialnych źródeł energii lub do źródeł wytwarzających energię elektryczną w kogeneracji z wyłączeniem wytwarzania energii elektrycznej z biogazu rolniczego,

2) ciepła w źródłach o łącznej mocy zainstalowanej cieplnej nieprzekraczającej $5 \mathrm{MW}$;

3) magazynowania paliw gazowych w instalacjach magazynowych, skraplania gazu ziemnego i regazyfikacji skroplonego gazu ziemnego w instalacjach skroplonego gazu ziemnego, jak również magazynowania paliw ciekłych, z wyłączeniem: lokalnego magazynowania gazu płynnego w instalacjach o przepustowości poniżej $1 \mathrm{MJ} / \mathrm{s}$ oraz magazynowania paliw ciekłych w obrocie detalicznym;

4) przesyłania lub dystrybucji paliw lub energii, z wyłączeniem: dystrybucji paliw gazowych w sieci o przepustowości poniżej $1 \mathrm{MJ} / \mathrm{s}$ 
oraz przesyłania lub dystrybucji ciepła, jeżeli łączna moc zamówiona przez odbiorców nie przekracza $5 \mathrm{MW}$;

obrotu paliwami lub energią, $\mathrm{z}$ wyłączeniem:

a. obrotu paliwami stałymi, obrotu energią elektryczną za pomocą instalacji o napięciu poniżej $1 \mathrm{kV}$ będącej własnością odbiorcy, obrotu paliwami gazowymi, jeżeli roczna wartość obrotu nie przekracza równowartości 100.000 euro, obrotu gazem płynnym, jeżeli roczna wartość obrotu nie przekracza równowartości 10.000 euro oraz obrotu ciepłem, jeżeli moc zamówiona przez odbiorców nie przekracza $5 \mathrm{MW}$,

b. obrotu paliwami gazowymi lub energią elektryczną dokonywanego na giełdzie towarowej.

W podanych powyżej przypadkach ustawodawca wymaga uzyskania koncesji, jako elementu prawno-administracyjnego, który ma zapewnić prawidłowość obrotu gospodarczego. Przypadki wskazane w ustawie - Prawo energetyczne, kiedy powinno się uzyskać koncesję mają charakter wyliczenia enumeratywnego. Oczywiście poza przypadki, gdzie wskazano, że warunkiem koniecznym jest posiadanie koncesji, określone zostają sytuacje, gdy koncesja nie jest wymagana. W związku z powyższym zdecydowano, iż uzyskanie koncesji nie wymaga wykonywania działalności gospodarczej w zakresie wytwarzania ciepła uzyskiwanego $\mathrm{w}$ przemysłowych procesach technologicznych, a także gdy wielkość mocy zamówionej przez odbiorców nie przekracza $5 \mathrm{MW}$ oraz wykonywanie działalności gospodarczej w zakresie obrotu benzyną lotniczą oznaczoną symbolem PKWiU 23.20.11-40 oraz objętą kodem CN 271011 31, jeżeli roczna wartość obrotu nie przekracza równowartości 1.000 .000 euro.

Jako element władztwa administracyjnego, ustawa zawiera legitymację do wydania rozporządzenia w sprawie dywersyfikacji gazu. I tak Rada Ministrów, na wniosek ministra właściwego do spraw gospodarki, określa $\mathrm{w}$ drodze rozporządzenia, minimalny poziom dywersyfikacji dostaw gazu z zagranicy poprzez ustalenie maksymalnego procentowego udziału gazu $\mathrm{z}$ jednego źródła. Akt wykonawczy do ustawy powinien określać poziom dywersyfikacji na okres co najmniej 10 lat. Normy prawne realizujące zapisy ustawowe zostały zrealizowa- 
ne w rozporządzeniu Rady Ministrów z dnia 24 października 2000 r. w sprawie minimalnego poziomu dywersyfikacji dostaw gazu z zagranicy (B). Delegacja ustawowa do powyższego rozporządzenia została zawarta w art. 32 ust. 3 ustawy - Prawo energetyczne.

Rada Ministrów zdecydowała, że maksymalny udział gazu importowanego z jednego kraju pochodzenia, w stosunku do całkowitej wielkości gazu importowanego w danym roku, nie może być wyższy niż:

1) $88 \%$ - w latach $2001-2002$,

2) $78 \%$ - w latach $2003-2004$,

3) $72 \%$ - w latach $2005-2009$,

4) $70 \%$ - w latach $2010-2014$,

5) $59 \%$ - w latach $2015-2018$,

6) $49 \%$ - w latach 2019-2020.

Zagadnieniem koncesji zajmuje się nie tylko teoria, ale również praktyka i orzecznictwo sądowe i administracyjne. Ze względu całe spektrum realizowanych zagadnień istotnym pozostaje fakt legitymizowania działań formalnych. $Z$ tego względu przy udzielaniu decyzji w przedmiocie udzielenia koncesji na obrót paliwami płynnymi należy brać pod uwagę fakt popełnienia przestępstwa polegającego na dokonywaniu obrotu paliwem ciekłym - olejem napędowym niespełniającym wymagań jakościowych pod względem składu frakcyjnego i zawartości siarki jako przestępstwa mającego związek z przedmiotem działalności gospodarczej określonej ustawą (C). Postępowanie sprawdzające pod względem formalnym winno wykazać, że podmiot ubiegający się koncesję spełnia warunki do jej otrzymania. Dlatego też w sprawie o wydanie koncesji na obrót paliwami ciekłymi, wnioskodawca powinien przedstawić organowi wszystkie niezbędne dokumenty, warunkujące dopuszczenie zbiorników paliwa do eksploatacji (D). Spełnienie przesłanek formalnych dotyczy zarówno działalności krajowego, jak i tej ogólnoeuropejskiej. W związku z tym w przypadku ubiegania się przez przedsiębiorstwo energetyczne o udzielenie koncesji na obrót paliwami gazowymi z zagranicą niezbędne jest przedstawienie informacji o kraju pochodzenia paliwa gazowego (E). Należy w tym miejscu zwrócić uwagę, że nieprzedłożenie Prezesowi URE, wbrew warunkom koncesji, sprawozdania $\mathrm{z}$ realizacji koncesjono- 
wanej działalności, uzasadnia nałożenie na przedsiębiorstwo energetyczne kary pieniężnej (F). Koncesja jako pozwolenie administracyjne dotyczy określonego zakresu działań. Koncesja na wytwarzanie energii nie obejmuje jej przesyłu i dystrybucji, na co wymagane jest posiadanie odrębnych koncesji $(\mathrm{G})$. Jednak oprócz czynności, które wyłączają możliwość uzyskania koncesji, ustawa daje możliwość prowadzenia działalności w szeroko pojętym sektorze energetycznym, bez konieczności uzyskiwania koncesji. Jeżeli żadne ze źródeł, w których przedsiębiorstwo wytwarza energię elektryczną, nie osiąga $5 \mathrm{MW}$, koncesja nie jest wymagana, choćby łączna moc tych źródeł osiągała lub przekraczała 5 MW.

Jeżeli zostaną spełnione przesłanki pozytywne Prezes Urzędu Regulacji Energetyki udziela koncesji wnioskodawcy, który:

1) ma siedzibę lub miejsce zamieszkania na terytorium państwa członkowskiego Unii Europejskiej, Konfederacji Szwajcarskiej lub państwa członkowskiego Europejskiego Porozumienia o Wolnym Handlu (EFTA) - strony umowy o Europejskim Obszarze Gospodarczym;

2) dysponuje środkami finansowymi w wielkości gwarantującej prawidłowe wykonywanie działalności bądź jest w stanie udokumentować możliwości ich pozyskania;

3) ma możliwości techniczne gwarantujące prawidłowe wykonywanie działalności;

4) zapewni zatrudnienie osób o właściwych kwalifikacjach zawodowych;

5) uzyskał decyzję o warunkach zabudowy i zagospodarowania terenu albo decyzję o ustaleniu lokalizacji inwestycji w zakresie budowy obiektu energetyki jądrowej.

Ustawa określa również zakres przedmiotowy wniosku o udzielenie koncesji, który powinien zawierać w szczególności:

1) oznaczenie wnioskodawcy i jego siedziby lub miejsca zamieszkania, a w razie ustanowienia pełnomocników do dokonywania czynności prawnych w imieniu przedsiębiorcy - również ich imiona i nazwiska;

2) określenie przedmiotu oraz zakresu prowadzonej działalności, na którą ma być wydana koncesja; 
3) informacje o dotychczasowej działalności wnioskodawcy, w tym sprawozdania finansowe $\mathrm{z}$ ostatnich 3 lat, jeżeli podmiot prowadzi działalność gospodarczą;

4) określenie czasu, na jaki koncesja ma być udzielona, wraz ze wskazaniem daty rozpoczęcia działalności;

5) określenie środków, jakimi dysponuje podmiot ubiegający się o koncesję, w celu zapewnienia prawidłowego wykonywania działalności objętej wnioskiem;

6) numer w rejestrze przedsiębiorców albo ewidencji działalności gospodarczej oraz numer identyfikacji podatkowej (NIP).

Koncesji udziela się na czas oznaczony, nie krótszy niż 10 lat i nie dłuższy niż 50 lat, chyba że przedsiębiorca wnioskuje o udzielenie koncesji na czas krótszy. Natomiast samo udzielenie koncesji może być uzależnione od złożenia przez wnioskodawcę zabezpieczenia majątkowego w celu zaspokojenia roszczeń osób trzecich, mogących powstać wskutek niewłaściwego prowadzenia działalności objętej koncesją, w tym szkód w środowisku. Powodem uzależnienia udzielenia koncesji od złożenia zabezpieczenia mogą być wątpliwości organu koncesyjnego dotyczące kondycji finansowej wnioskodawcy $(\mathrm{H})$.

Przedstawiona analiza potwierdza przedstawioną tezę o rozbudowanym otoczeniu legislacyjnym dotyczącym sektora energetycznego, które spełnia rolę prewencyjną, jak również powoduje, że na rynku funkcjonują podmioty, które gwarantują stabilność sektora.

\section{Bibliografia}

(A) Ustawa - Prawo energetyczne z dnia 10 kwietnia 1997 r. (Dz. U. z 2006 r. Nr 89, poz. $625, \mathrm{z}$ późn. $z$ m.).

(B) Rozporządzenie Rady Ministrów z dnia 24 października 2000 r. w sprawie minimalnego poziomu dywersyfikacji dostaw gazu z zagranicy (Dz. U. z 2000 r., Nr 95, poz. 1042).

(C) Wyrok Sądu Apelacyjnego w Warszawie z dnia 6 grudnia 2007 r. VI ACa 845/07.

(D) Wyrok Wojewódzkiego Sądu Administracyjnego w Warszawie z dnia 10 lipca 2007 r.

(E) Wyrok Wojewódzkiego Sądu Administracyjnego w Warszawie z dnia 25 października 2005 r. VI SAB/Wa 27/05.

(F) Wyrok Sądu Antymonopolowego z dnia 14 listopada 2001 r. XVII Ame 97/00.

(G) Wyrok Sądu Antymonopolowego z dnia 12 września 2001 r. XVII Ame 65/00.

(H) Wyrok Sądu Najwyższego z dnia 16 kwietnia 2008 r. III SK 33/07. 


\section{STRESZCZENIE}

Koncesje stanowią jeden z elementów regulowania obrotu gospodarczego. W ustawie Prawo energetyczne wskazuje się na przesłanki uzyskania koncesji na wytwarzanie energii. Ze względu na istotne znaczenie sektora energetycznego dla szerokiego pojęcia bezpieczeństwa państwa, sprawy dotyczące procedur koncesyjnych zostały uregulowane ustawą oraz aktami wykonawczymi.

\section{Legal and administrative nature of concessions in Energy Law}

\section{SUMMARY}

Concessions are one of the elements of regulation of economic activity. Energy Law stipulates the conditions for obtaining a license for the production of energy. Due to the importance of the energy sector to the security of the State, matters relating to licensing procedures are regulated by Law and Regulations. 